\title{
OBSERVATIONS ON THE TOXIC EFFECTS OF CORDITE
}

\author{
BY
}

\author{
J. S. WEINER and M. L. THOMSON
}

From the Royal Naval Personnel Research Committee of the Medical Research Council

(RECEIVED FOR PUBLICATION, APRIL, 1947)

The main object of the present trials was to ascertain whether ill effects attributable to cordite could be reproduced experimentally. Additional aims were to obtain information on (1) the mode of absorption. of cordite, (2) the influence of cordite fumes on the efficiency of operatives at ambient and at high wet-bulb temperatures, (3) the occurrence of any acquired immunity, (4) the extent, if any, to which carbon dioxide might contribute to the symptoms, and (5) the concentration of nitrogen dioxide and carbon monoxide released during cordite handling in addition to the vapour of nitroglycerine.

\section{Methods}

Trial Room.-A trial room (fig. 1, p. 230) was erected in a building provided with steam and dry heat. The plan (fig. 2) shows the dimensions of the two parts of the airtight room-(1) the space $(380 \mathrm{cu}$. $\mathrm{ft}$.) in which four subjects and two observers were accommodated, and in which the cordite was handled and (2) the stowage section at one end, in which twenty cordite cases were stacked in five horizontal rows of four each (fig. 3). In the hot experiments the trial room was heated by raising the temperature of the outer room. Some control over the dry-bulb temperature was obtained by regulating the steam heating and by spraying the metal roof of the trial room, on to which a fan was directed.

Subjects.-The subjects were eight healthy young men of aged 20 to 25 years, who were medically examined and had their chests radiographed before leaving barracks. They were arranged in two teams of four, each team subdivided into two pairs.

Clothing.-Clothing consisted of a single-piece overall worn over a pair of shorts, anti-flash helmet (with mask), anti-flash gloves, socks, and plimsolls. One member of each pair wore in addition a rubber apron, with full length sleeves, extending from neck to knees. The antiflash gloves were replaced by rubber gauntlet gloves into which the sleeves of the apron were tucked. This dress protected the wearer's skin from contact with the cordite, and was worn by each man on alternate days.

Cordite.-The cordite was packed in metal cases containing two charges each of $96 \mathrm{lb}$. weight. It had been stoved for five months at $120^{\circ} \mathrm{F}$. Each charge consisted of many cylindrical cordite rods (average diameter 0.2 inches) enclosed in a silk bag.

c
Analysis of carbon dioxide, nitrous fumes (nitrogen dioxide), and carbon monoxide of the air within these cases revealed marked variations from case to case. Since full analysis of the gases was possible in a limited number only, the cases were arranged on the basis of their carbon dioxide content, as this was found to show a fair positive relationship to the carbon monoxide content, but no correlation with the nitrogen dioxide content. The cases to be opened were then preselected so as to give, as far as possible, an equal proportion of these gases during each trial and also during each work period.

Dummy Charges.-These were intended to be replicas of the cordite charges. They weighed $108 \mathrm{lb}$. (against $96 \mathrm{lb}$. for the cordite charges) and were packed in pairs in the ordinary cases. The fabric surrounding the dummy was, however, different from that of the cordite charges, and it was not difficult for the men to detect which of the two they were handling.

\section{Observations}

Air Analysis.-Samples of air taken from the cordite cases, as well as from the experimental room at intervals during the trials, were analysed for nitrogen dioxide by the Greiss-Ilosvay method, for carbon monoxide by the iodine-pentoxide method, and for oxygen and carbon dioxide by Haldane and Orsat gas analysis apparatus. Attempts to estimate nitro-glycerine (N.G.) vapour in the presence of the much higher nitrogen dioxide content were unsuccessful.

Physiological.-The men were weighed nude at the beginning and again at the end of each trial. Their net body-weight loss was determined, making allowance for water drunk and urine output. Water was allowed in any quantity. The clothing, including rubber protective garments when worn, was weighed at the beginning and at the end. Pulse rates were counted in the standing position before commencing work and in the first half minute after stopping work. Respiratory rate was counted in the standing position before work and in the second minute after stopping work. Blood pressures were measured in every case after a preliminary period in which the subject sat quietly for five minutes. The blood pressures in the standing position were taken one minute after the erect posture was assumed. Rectal temperatures were measured before and after each work bout. 
Fitness Index.-An assessment of the ease with which the man performed the work was attempted by questioning the subject, and from the observer's opinion of his condition. The following rating was used: Grade 1, perfectly able to continue work; Grade 2, able to finish work but doubtful if a second bout could be done efficiently ; Grade 3, able to finish work, but work done inefficiently, and/or work followed by symptoms of faintness ; Grade 4, able to finish work but work done inefficiently and followed by collapse; or unable to finish work.

Subjective Reactions.-The men were questioned regarding their general condition with a view to ascertaining the incidence, if any, of headache. No leading question on this point was asked, but after the first cordite trials implications of this questioning were, of course, appreciated by the men.

Body Fluid Estimations.-A few preliminary estimations of whole blood nitrites were made. Methæmoglobin concentration was estimated on one occasion by Dr. Jope of the London Hospital. Blood examinations and urine analyses were carried out by Dr. R. Case, of the Royal Naval Physiological Laboratory.

Routine of Trials.-The duration of each trial was three hours. Each couple performed two twentyminute periods of work at the commencement and at the end of every trial. During each work period in cordite trials, four cases were opened and the cordite charges carried to the racks (fig. 2) and then replaced in the cases. Thus sixteen fresh cases of cordite were opened each day.

Blood pressure, rectal temperature, and pulse were taken before and after each work period except in the case of protected men where blood pressure readings had to be omitted after the first and before the second work.

The atmosphere of the trial room was sampled on entry and at the end of the first, second, and third hours.

The procedure on Dummy trial days was identical except that the cordite cases were replaced by dummy cases. The programme of trials is shown in Table 1.

As can be seen, the experiments were arranged so that (a) dummy experiments preceded and followed the two cordite trials in both ' hot' and 'cold' series, to allow for any effect of repetition in improving the performance, especially at high temperatures, and $(b)$ three clear days, with one exception, were allowed between successive exposures to cordite.

\section{Results}

Observations on " Aged" Cordite Products.-Estimations of carbon dioxide were carried out on the gas within each of the 128 cases used ; nitrogen dioxide and carbon monoxide were determined in 18 cases and oxygen in 7 cases only. A marked variation was found from case to case in the concentrations of these gases, ranging from 0.10 per cent. to 24 per cent. in the case of carbon dioxide ; from 4.5 per cent. to 20.8 per cent. of oxygen, and from 0.00005 to 0.6 per cent. of carbon monoxide.

There was an inverse relationship between the oxygen and carbon dioxide contents of each of the 7 cases. There was a fair relationship between carbon dioxide and carbon monoxide contents; carbon dioxide and nitrogen dioxide concentrations did not appear to be related.

The concentration of nitroglycerine vapour could only be inferred from its known vapour pressure. It was. presumably the same in all of the cases, and was calculated to be of the order of 0.0000003 per cent. W/V during " cold" weather trials.

The dead space in each case is about 20 litres, and 16 were opened during each trial, so that 320 litres of case air were diluted by 10,000 litres of room air (31x).

The cases were so constructed as to be flashtight. It was noticed, however, during sampling, that the contents were invariably at or about atmospheric pressure under temperature changes which involved expansion and contraction of the gases, and further tests by manometer confirmed that few, if any, of the cases were airtight.

A few samples were taken during hot trials close to the case as the charge was being withdrawn during work. Nitrogen dioxide was 0.00012 per cent. to 0.0004 per cent. and carbon monoxide a 'trace' to 0.002 per cent. These figures are unlikely to represent the maximum concentrations to which the men were exposed while withdrawing charges.

A pair of anti-flash gloves was analysed for nitroglycerine after the second cold cordite (May 7, 1946) and again after the second hot cordite (June 4, 1946) trials. The average weight of each glove was $50 \mathrm{~g}$. On May 7, 1946, weight of nitroglycerine in the left glove was 0.0680 g., and of the right glove $0.0599 \mathrm{~g}$. On June 4, 1946, the

TABLe 1

PROGRAMME OF TRIALS

\begin{tabular}{|c|c|c|c|}
\hline Date & Experiment & Conditions & Team \\
\hline $\begin{array}{r}\text { April, } 1946 \\
\text { Mon. } 29 \\
\text { Tues. } 30\end{array}$ & $\begin{array}{c}\text { Dummy } \\
\text {, }\end{array}$ & $\begin{array}{c}\text { Cold } \\
\text { " }\end{array}$ & $\begin{array}{l}\mathbf{B} \\
\mathbf{A}\end{array}$ \\
\hline $\begin{array}{c}\text { May, } 1946 \\
\text { Thur. } 2 \\
\text { Fri. } 3 \\
\text { Mon. } 6 \\
\text { Tues. } 7 \\
\text { Thur. } 9 \\
\text { Fri. } 10\end{array}$ & $\begin{array}{c}\text { Cordite } \\
, " \\
\text { ", } \\
\text { Dummy }\end{array}$ & $\begin{array}{l}\text { " } \\
\text { " } \\
\text { ", } \\
\text { ", }\end{array}$ & $\begin{array}{l}\mathbf{B} \\
\mathbf{A} \\
\mathbf{B} \\
\mathbf{A} \\
\mathbf{B} \\
\mathbf{A}\end{array}$ \\
\hline
\end{tabular}

Mon. 13 )

to 18$\}$ First week.of acclimatization

Sat. 18

Mon. 20 to 25$\}$

Second week of acclimatization

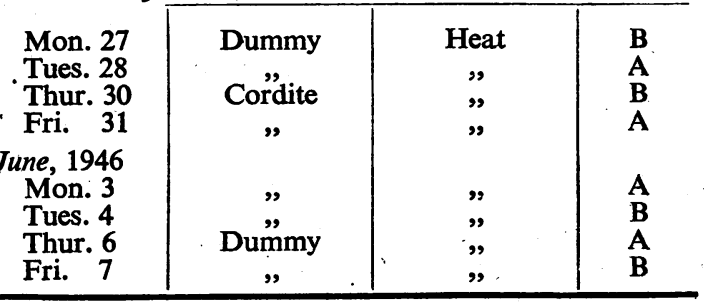


weight of nitroglycerine in the left glove was $0.0177 \mathrm{~g}$. and in the right glove $0.0045 \mathrm{~g}$. These amounts of nitroglycerine were probably concentrated in the palms of the gloves and anterior surfaces of the gauntlets.

\section{Environmental Observations}

Concentrations of $\mathrm{NO}_{2}$ and $\mathrm{CO}$ in the Trial Room.With few exceptions nitrogen dioxide and carbon monoxide were maximal in the terminal sample (Tables 2 and 3). The final nitrogen dioxide figures were in cold trials from $\mathbf{0 . 0 0 0 2}$ per cent. to 0.0007 per cent., and in hot trials from 0.0001 per cent. to 0.0004 per cent. ; corresponding carbon monoxide figures were 0.001 per cent. to 0.002 per cent. in cold trials and "traces" to 0.001 per cent. in hot trials.

The average of all analyses of nitrogen dioxide for " cold " trials was $\mathbf{0 . 0 0 0 3 2}$ per cent. and for hot trials was 0.00015 per cent.; corresponding figures for carbon monoxide were 0.0011 per cent. and 0.00057 per cent. From these figures it can be seen that the average concentration of these gases was twice as high during exposure to cold temperature as it was during hot trials.

TABLE 2

ATMOSPHERIC CONDITIONS DURING TRIALS IN TEMPERATE ENVIRONMENTS

\begin{tabular}{|c|c|c|c|c|c|}
\hline \multicolumn{6}{|c|}{ Team A (4 subjects) } \\
\hline \multirow{2}{*}{$\begin{array}{l}\text { Date } \\
\text { and } \\
\text { trial }\end{array}$} & \multirow{2}{*}{$\begin{array}{c}\text { Dry } \\
\text { bulb } \\
\left(\text { av. }^{\circ} F_{\text {. }}\right)\end{array}$} & \multirow{2}{*}{$\begin{array}{c}\text { Wet } \\
\text { bulb } \\
\text { (av. }{ }^{\circ} \text { F.) }\end{array}$} & \multicolumn{3}{|c|}{$\begin{array}{l}\text { Air concentrations } \\
\text { (at end) }\end{array}$} \\
\hline & & & $\mathrm{CO}_{\%}$ & $\underset{\%}{\mathrm{NO}_{2}}$ & $\begin{array}{c}\mathrm{CO} \\
\%\end{array}$ \\
\hline $\begin{array}{l}30.4 .46 \\
\text { Dummy }\end{array}$ & $\begin{array}{c}75 \cdot 6 \\
(71 \cdot 5-79 \cdot 0)\end{array}$ & $\begin{array}{c}68 \cdot 2 \\
(65 \cdot 5-75 \cdot 0)\end{array}$ & $3 \cdot 6$ & & \\
\hline $\begin{array}{l}2.5 .46 \\
\text { Cordite }\end{array}$ & $\begin{array}{c}71 \cdot 6 \\
(65 \cdot 0-75 \cdot 0)\end{array}$ & $\begin{array}{c}66 \cdot 4 \\
(60 \cdot 8-70 \cdot 0)\end{array}$ & $4 \cdot 0$ & 0.00020 & 0.0014 \\
\hline $\begin{array}{l}6.5 .46 \\
\text { Cordite }\end{array}$ & $\begin{array}{c}67 \cdot 9 \\
(60 \cdot 0-71 \cdot 5)\end{array}$ & $\begin{array}{c}62 \cdot 8 \\
(55 \cdot 6-66 \cdot 5)\end{array}$ & $3 \cdot 6$ & 0.00067 & 0.0008 \\
\hline $\begin{array}{l}9.5 .46 \\
\text { Dummy }\end{array}$ & $\begin{array}{c}72 \cdot 2 \\
(65 \cdot 2-74 \cdot 0)\end{array}$ & $\begin{array}{c}64 \cdot 9 \\
(59 \cdot 6-68 \cdot 5)\end{array}$ & $3 \cdot 2$ & 0.00025 & 0.0002 \\
\hline
\end{tabular}

Team B (4 subjects)

\begin{tabular}{|c|c|c|c|c|c|}
\hline $\begin{array}{l}29.4 .46 \\
\text { Dummy }\end{array}$ & $\begin{array}{c}70 \cdot 5 \\
(65 \cdot 0-72 \cdot 5)\end{array}$ & $\begin{array}{c}65 \cdot 4 \\
(60 \cdot 0-67 \cdot 5)\end{array}$ & $3 \cdot 1$ & & \\
\hline $\begin{array}{l}3.5 .46 \\
\text { Cordite }\end{array}$ & $\begin{array}{c}71 \cdot 2 \\
(67 \cdot 5-74 \cdot 0)\end{array}$ & $\begin{array}{c}67 \cdot 0 \\
(59 \cdot 0-69 \cdot 5)\end{array}$ & $4 \cdot 1$ & 0.00021 & 0.0018 \\
\hline $\begin{array}{l}\text { 7.5.46 } \\
\text { Cordite }\end{array}$ & $\begin{array}{c}69 \cdot 2 \\
(65 \cdot 0-74 \cdot 0)\end{array}$ & $\begin{array}{c}64 \cdot 6 \\
(59 \cdot 0-69 \cdot 5)\end{array}$ & $4 \cdot 0$ & 0.00045 & 0.0020 \\
\hline $\begin{array}{l}10.5 .46 \\
\text { Dummy }\end{array}$ & $\begin{array}{c}72 \cdot 3 \\
(64 \cdot 8-76 \cdot 9)\end{array}$ & $\begin{array}{c}66 \cdot 6 \\
(59 \cdot 2-71 \cdot 3)\end{array}$ & $3 \cdot 6$ & & \\
\hline
\end{tabular}

TABLE 3

ATMOSPHERIC CONDITIONS DURING TRIALS IN HOT ENVIRONMENTS

Team A (4 subjects)

\begin{tabular}{|c|c|c|c|c|c|}
\hline \multirow{2}{*}{$\begin{array}{l}\text { Date } \\
\text { and } \\
\text { trial }\end{array}$} & \multirow{2}{*}{$\begin{array}{c}\text { Dry } \\
\text { bullb } \\
\left(\text { av. }{ }^{\circ} \mathrm{F} \text {.) }\right.\end{array}$} & \multirow{2}{*}{$\begin{array}{l}\text { Wet } \\
\text { bulb } \\
\text { (av. }{ }^{\circ} \text { F.) }\end{array}$} & \multicolumn{3}{|c|}{$\begin{array}{c}\text { Air concentrations } \\
\text { (at end) }\end{array}$} \\
\hline & & & $\underset{\%}{\mathrm{CO}_{2}}$ & $\begin{array}{c}\mathrm{NO}_{2} \\
\%\end{array}$ & $\begin{array}{c}\mathrm{CO} \\
\%\end{array}$ \\
\hline $\begin{array}{l}28.5 .46 \\
\text { Dummy }\end{array}$ & $\begin{array}{c}89 \cdot 0 \\
(88 \cdot 4-89 \cdot 5)\end{array}$ & $\begin{array}{c}86 \cdot 7 \\
(81 \cdot 5-88 \cdot 2)\end{array}$ & $4 \cdot 2$ & & \\
\hline $\begin{array}{l}31.5 .46 \\
\text { Cordite }\end{array}$ & $\begin{array}{c}\dot{88} \cdot 6 \\
(88 \cdot 0-89 \cdot 0)\end{array}$ & $\begin{array}{c}86 \cdot 6 \\
(79 \cdot 5-88 \cdot 2)\end{array}$ & $4 \cdot 2$ & 0.00037 & Traces \\
\hline $\begin{array}{l}3.6 .46 \\
\text { Cordite }\end{array}$ & $\begin{array}{c}88 \cdot 5 \\
(85 \cdot 5-90 \cdot 5)\end{array}$ & $\begin{array}{c}86 \cdot 2 \\
(77 \cdot 8-89 \cdot 2)\end{array}$ & $4 \cdot 3$ & 0.00012 & 0.0010 \\
\hline $\begin{array}{l}6.6 .46 \\
\text { Dummy }\end{array}$ & $\begin{array}{c}88: 3 \\
(87 \cdot 0-89 \cdot 0)\end{array}$ & $\begin{array}{c}85 \cdot 6 \\
(79 \cdot 8-85 \cdot 6)\end{array}$ & - & 0.00009 & Traces \\
\hline
\end{tabular}

Team B (4 subjects)

\begin{tabular}{|c|c|c|c|c|c|}
\hline $\begin{array}{c}\text { (24.5.46 } \\
\text { Dummy } \\
\text { prelim- } \\
\text { inary) }\end{array}$ & $\begin{array}{c}91 \cdot 8 \\
(90 \cdot 0-92 \cdot 6)\end{array}$ & $\begin{array}{c}90 \cdot 7 \\
(85 \cdot 8-92 \cdot 3)\end{array}$ & 3.8 & & \\
\hline $\begin{array}{l}27.5 .46 \\
\text { Dummy }\end{array}$ & $\begin{array}{c}87 \cdot 3 \\
(85 \cdot 8-88 \cdot 8)\end{array}$ & $\begin{array}{c}84 \cdot 3 \\
(79 \cdot 0-86 \cdot 1)\end{array}$ & - & 0.00021 & Traces \\
\hline $\begin{array}{l}30.5 .46 \\
\text { Cordite }\end{array}$ & $\begin{array}{c}90 \cdot 3 \\
(88 \cdot 0-93 \cdot 0)\end{array}$ & $\begin{array}{c}87 \cdot 8 \\
(81 \cdot 5-92 \cdot 0)\end{array}$ & $4 \cdot 0$ & 0.00026 & 0.0006 \\
\hline $\begin{array}{l}4.6 .46 \\
\text { Cordite }\end{array}$ & $\begin{array}{c}87 \cdot 35 \\
(87 \cdot 0-89 \cdot 0)\end{array}$ & $\begin{array}{c}84 \cdot 1 \\
(79 \cdot 2-87 \cdot 0)\end{array}$ & $4 \cdot 1$ & 0.00018 & 0.0008 \\
\hline $\begin{array}{l}7.6 .46 \\
\text { Dummy }\end{array}$ & $\begin{array}{c}90.95 \\
(88 \cdot 5-91 \cdot 2)\end{array}$ & $\begin{array}{c}87 \cdot 4 \\
(77 \cdot 5-90 \cdot 5)\end{array}$ & $3 \cdot 6$ & & \\
\hline
\end{tabular}

It is also interesting that in the dummy trials in which air was analysed the nitrogen dioxide and carbon monoxide concentrations were of the order found in some of the hot cordite trials. This may indicate the difficulty of ensuring the complete absence of cordite gases from the vicinity.

$\mathrm{CO}_{2}$ Concentrations. - The concentrations reached at the end of the trials are shown in Tables 2 and 3. These are, physiologically speaking, quite high, but it must be remembered that concentrations over 3 per cent. were only breathed during the last hour of the experiment. It will be noted that the carbon dioxide percentages are, with two exceptions, lower at the end of dummy trials than at the end of cordite trials. The probable explanation is that the two observers had a good deal more physical exertion to perform during the cordite runs, in taking off the lids which were often almost immovable, and in groping for and extracting a wooden disc from the 
far end of the cylinder. As is reported below, the oxygen cost of the work was not substantially different, whether dummy or cordite charges were handled.

Thermal Conditions.-During exposure at temperate conditions (Table 2 ) the dry-bulb and wet-bulb temperatures rose rapidly in the first half hour by $2^{\circ}$ to $5^{\circ} \mathrm{F}$. in different experiments, and then more slowly in the remaining hour and a half-a further $3^{\circ}$ to $6^{\circ} \mathrm{F}$. In some of the high-temperature experiments (Table 3) the rise in dry-bulb temperature was only $2^{\circ} \mathrm{F}$. throughout, owing to the improved control measures which were instituted as a result of experience. The wet-bulb, however, as in the cooler conditions, rose rapidly in the first twenty to thirty minutes and then more slowly. It should be noted that during the most important part of the exposure, namely, for three out of the four work periods performed by the two teams, the temperature rise was only about $2^{\circ} \mathrm{F}$. in dry bulb or wet bulb. At high temperatures this increase means, of course, that the second work was done at a wet-bulb temperature physiologically appreciably more severe than that of the first work spell.

Table 2 shows that both teams performed one cordite trial at temperatures a little below either of the dummy runs. On the whole the differences between the series of dummy and cordite trials have not been regarded as significant from the view point of the present trials. The results of the temperate trials of both teams have accordingly been treated together.

In the case of the trials at high temperatures it has been thought better, for the most part, to treat the results for the two teams separately. As Table 3 indicates, the thermal conditions were far more comparable in the case of team A than in the case of team B. For the latter it is possible to compare equivalent sets of conditions by taking the first dummy trial in relation to the second cordite trial and the second dummy trial in relation to the first cordite trial. This procedure to some extent tends to equalize the differences in acclimatization between the two pairs ; fortunately the pairs are comparable also, in that the same sets of clothing were worn by the same individuals. It may be said at once that in spite of the divergences of treatment undergone by the two teams, the main results are in most particulars very similar.

Estimations of the air movement carried out in five points in the room, both when the men were resting and when they were working, revealed very low air speeds, viz., 8 feet per minute at rest, 20 feet per minute when at work. The work created little air movement because each journey was so short and so infrequent.

Oxygen Cost of the Work.-There was a marked difference in weight between the dummy and cordite charges, namely, $108 \mathrm{lb}$. as compared to $96 \mathrm{lb}$. On this account any of the effects of cordite would have been under-estimated. On the other hand, the "aged" cordite coverings were sticky, and this made it rather more difficult to remove the charges from the cylinders. In the event the actual determinations of oxygen consumption gave a result very similar for the two types of charge ; the cost of twenty minutes' handling of either cordite or dummy, followed by thirty minutes' recovery, was, for a subject (CO) well practised in the method, $240 \mathrm{~kg}$. calories per hour. The oxygen cost of the work itself, measured after a preliminary ten minutes work, was found to be $310 \mathrm{~kg}$. calories per hour. Wearing the rubber gloves and apron in the cold did not increase the oxygen cost appreciably.

\section{Physiological Findings}

Subjective Effects.-On cold cordite trials every person taking part experienced irritation of the nose and throat, which caused intense congestion of the nasal mucous membrane, sneezing, and coughing. This passed off, but was noticed again every time a fresh batch of cases was opened. This irritant effect was less noticeable on hot cordite days.

Tables 4 and 5 set out the incidence of headaches during and after the work routine throughout the experimental series.

At ambient air temperatures the Tables show that headaches were complained of both by the observers and by subjects handling cordite. Headaches were noticed during the first work spell in some cases, but were reported on more frequently after the commencement of the second spell. On the first cordite day, at ambient temperatures, five of the eight subjects reported symptoms during the second work, and, after leaving the experimental room, six of the eight reported headaches. The two subjects who did not complain, namely $\mathrm{CO}$ of team A and JA of team B, appeared to be consistently immune in this respect, both in these trials and in those at high temperatures. A comparison of the second cordite day with the first cordite day at both temperatures with regard to incidence of headaches suggests that some immunity or tolerance was acquired ; the intensity of the headache was also, on the whole, less severe.

During the two days when cordite was handled in hot surroundings, headaches were reported during exposure by the subjects of team $B$ only; one subject of team $A$ complained of headache only after leaving the room. The observers of both teams complained of headaches on six out of eight exposures. In all, seven out of twelve individuals exposed suffered headaches on the first cordite day and five out of twelve on the second. The incidence in hot conditions appears to be less than in the cold series. The character of the headache was similar, but on the whole less severe.

The outstanding characteristics of the headache were its severity and its frontal situation (which was invariably reported). With time the headache often spread to the vertex. Unlike some reports in the literature, the headache was never described as "throbbing," though one individual said it " lifted the top of his head off." In many cases the headache passed off for a while during the trial, but returned later, usually on leaving the trial room, and persisted a variable time up to twenty-four hours. When severe there were symptoms of nausea, and in several cases there were complaints of abdominal pain.

Fitness Rating.-Tables 4 and 5 show the fitness ratings assessed before and after each work throughout the 
experimental series. In temperate environments cordite handling was performed, according to the subjects, " not quite so easily as in dummy runs." This opinion was not expressed only by those men with headaches. However, we do not consider that at these temperatures the men were demonstrably affected as regards performance.

At high temperatures the picture was very different. On both occasions when cordite was handled by team $\mathrm{A}$ at high wet-bulb temperatures, the ability to carry out the second bout of work was impaired. Although the work spell was completed in every case (with one exception) the condition of the men during and after the work was much poorer than on dummy days. As indicated in Table 5, the men came near to collapse on half the occasions during cordite trials, with pallor, dizziness, and feelings of faintness.

In the case of team B essentially similar results were found. At the higher wet-bulb temperature $\left(87^{\circ} \mathrm{F}\right.$.) one of the four men came near to fainting after the second bout of work. At the lower wet-bulb temperature $\left(84^{\circ} \mathrm{F}\right.$.) although there was no collapse, the men were undoubtedly in a worse state than on the corresponding dummy day.

Blood Pressure.-The effects on the blood pressure of cordite handling in ambient temperatures is shown in Table 6, which gives the averages for all eight subjects, sitting and standing ; the "protected" (P) and " unprotected" (U) findings are shown separately. The effect of cordite, as can be seen, is to produce a consistently greater fall in systolic blood pressure (S.B.P.) than occurs in dummy experiments. This effect was shown on eight out of ten occasions sitting, and on nine out of ten occasions standing.

The high temperature results are shown in Tables 7A and 7B, for teams $A$ and $B$ respectively. As in the cold, cordite produced a specific increase in the fall of S.B.P.;

TABLE 4

EFFECT ON SUBJECTIVE REACTIONS AND WORK PER FORMANCE OF CORDITE AND DUMMY HANDLING IN TEMPERATE ENVIRONMENTS

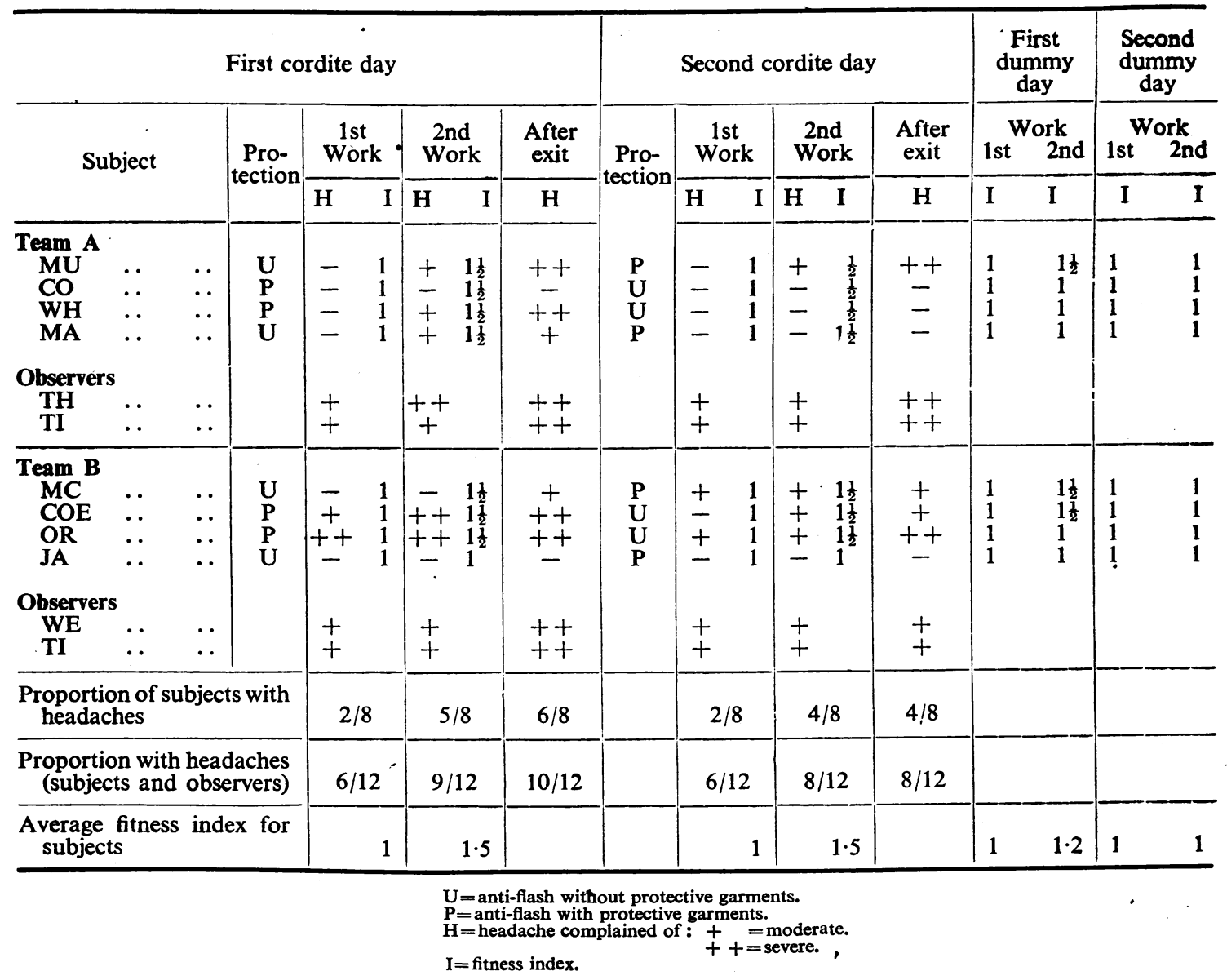


that is to say, over and above the fall due to heat alone. The proportion of observations in which this fall was demonstrated was fourteen out of sixteen (sitting) and fifteen out of sixteen (standing).

This effect of cordite has been analysed statistically (Table 8) by taking results comparable as regards clothing, the individual, and the temperature conditions. The mean difference between the change in S.B.P. in the dummy and cordite trials respectively, as compared with its standard deviation, gives $a$ ' $t$ ' test result of $P=0.05$ to 0.02 (sitting and standing) in temperate conditions, and $\mathbf{P}=0.001$ (sitting and standing) in hot conditions.

The probability, therefore, of the present findings occurring as the result of random variations is small.

A more detailed analysis of the data for the two teams; both in the cold and in the heat, revealed no regular difference between protected and unprotected clothing.
The diastolic blood pressure almost invariably rose during the trials. Tables $6,7 \mathrm{~A}$, and $7 \mathrm{~B}$ also show that the pulse pressure nearly always diminished more during cordite trials than during dummy trials.

Pulse and Respiratory Rates (Tables 6, 7A, and 7B).Wearing the protected clothing increased the pulse rate in both the hot and the cold trials. The effect of cordite was not consistent throughout. In the cold the average increase in pulse rate was greater as the result of handling cordite. This was shown also in the heat by team $\mathbf{A}$, but not by team $B$.

The respiratory rate increased more in the cordite trials than in the dummy trials. This was possibly due to the somewhat higher carbon dioxide concentration attained during the cordite experiments (Tables 2 and 3).

TABLE 5

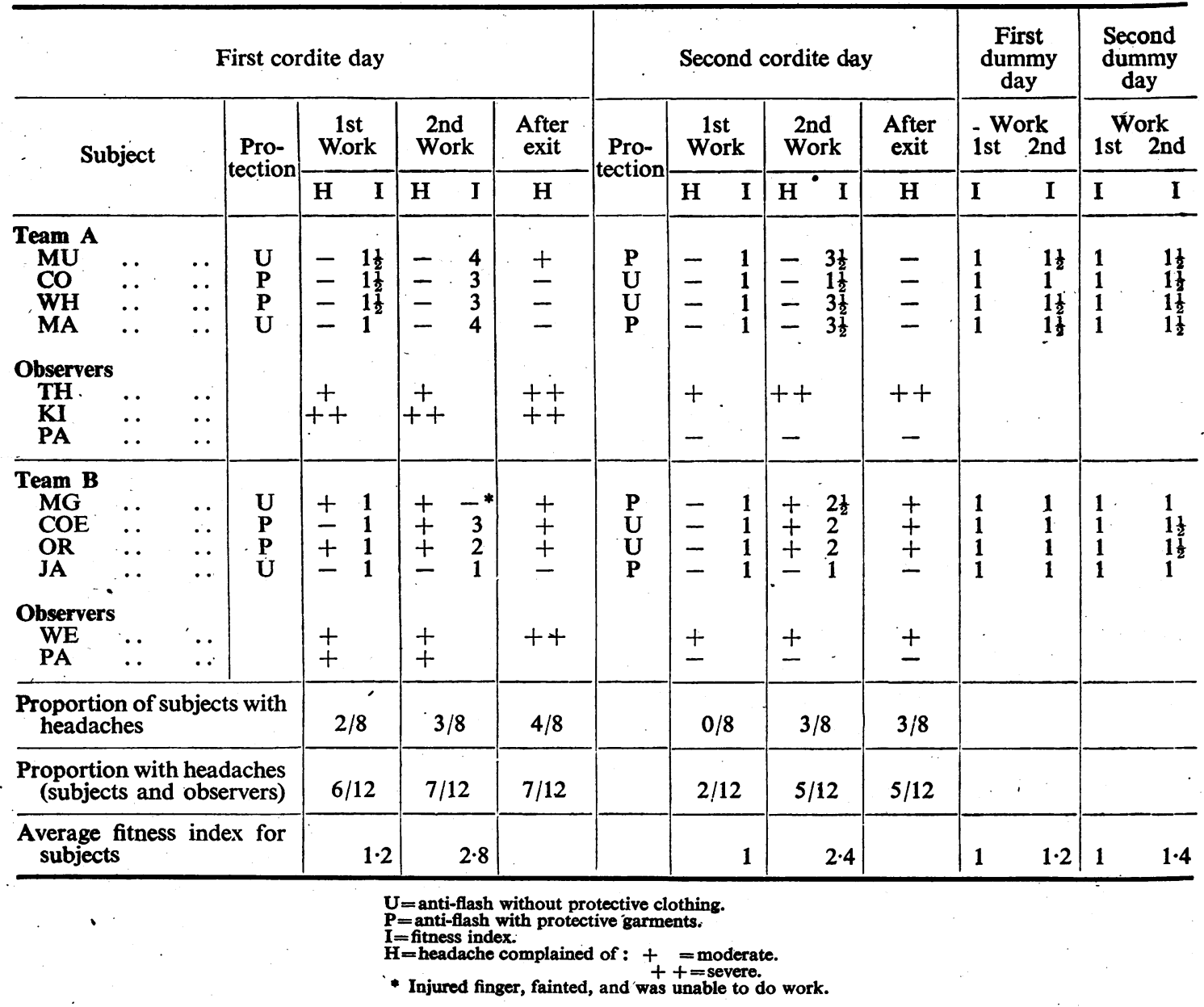


Rectal Temperatures.-There was no difference in rectal temperatures between cordite and dummy trial days. The rise in rectal temperature as the result of the two work spells in the heat, though small, was little higher in the case of protective garments. The slight rise in rectal temperature was to be expected as the result of the moderate rate of the work.

Weight Loss.-No constant difference was found as the result of cordite. As was to be expected, the protective clothing increased the weight loss. The rate of sweating as shown in the Tables was not very high in relation to the high wet-bulb temperature and still air conditions, pointing again to the relatively low rate of work. It is possible, of course, that incomplete acclimatization may also have been a factor. A comparison on this score between the first and last dummy experiments in the heat, as well as between the first and second cordite days (Table 1) does not, as far as the data permit, support the latter suggestion.

Unevaporated Sweat.-As expected, there was a greater amount of sweat in the clothes when wearing protective garments, but cordite did not produce a consistent effect.

Blood and Urine Tests : Radiograph of Chest.-The blood of one of the authors was submitted to spectrographic analysis three and a half hours after the end of a cordite trial, while he still had a severe headache, by Dr. Jope of the London Hospital. It was found to contain less than $\mathbf{0 . 2}$ per cent. of methæmoglobin and to be completely normal in this respect.

TABLE 6

PHYSIOLOGICAL EFFECTS OF CORDITE AND DUMMY HANDLING IN TEMPERATE CLIMATES : DUMMY TRIALS (TWO DAYS)

\begin{tabular}{|c|c|c|c|c|c|c|c|c|c|c|c|c|c|c|}
\hline & & & \multicolumn{4}{|c|}{ First work } & \multicolumn{4}{|c|}{ Second work } & \multirow{2}{*}{\multicolumn{2}{|c|}{$\begin{array}{l}\text { Col. } 1 \text { vs. } \\
\text { Col. } 4\end{array}$}} & \multirow{2}{*}{\multicolumn{2}{|c|}{$\begin{array}{l}\text { Col. } 2 \text { vs. } \\
\text { Col. } 4\end{array}$}} \\
\hline & & & \multicolumn{2}{|c|}{ Before } & \multicolumn{2}{|c|}{ After } & \multicolumn{2}{|c|}{ Before } & \multicolumn{2}{|c|}{ After } & & & & \\
\hline & & & $\mathrm{U}$ & $\mathbf{P}$ & $\mathrm{U}$ & $\mathbf{P}$ & $\mathrm{U}$ & $\mathbf{P}$ & $\mathrm{U}$ & $\mathbf{P}$ & $\mathbf{U}$ & $\dot{\mathbf{P}}$ & U & $\mathbf{P}$ \\
\hline $\begin{array}{l}\text { B.P. Sitting } \\
\text { Sys. P. } \\
\text { Dias. P. } \\
\text { Pulse P. }\end{array}$ & $\begin{array}{l}\ddot{.} \\
\ddot{*}\end{array}$ & $\begin{array}{l}\cdots \\
\cdots \\
\cdots\end{array}$ & $\begin{array}{r}110 \cdot 0 \\
60 \cdot 0 \\
45 \cdot 4\end{array}$ & $\begin{array}{r}110 \cdot 0 \\
63 \cdot 0 \\
47 \cdot 0\end{array}$ & $\begin{array}{r}110 \cdot 5 \\
64 \cdot 3 \\
46 \cdot 2 \\
\end{array}$ & & $\begin{array}{r}106 \cdot 0 \\
65 \cdot 9 \\
40 \cdot 1\end{array}$ & & $\begin{array}{r}107 \cdot 9 \\
65 \cdot 3 \\
42 \cdot 6 \\
\end{array}$ & $\begin{array}{r}101 \cdot 0 \\
66 \cdot 0 \\
35 \cdot 0 \\
\end{array}$ & $\begin{array}{r}-2 \cdot 1 \\
+\quad 5 \cdot 3 \\
-7 \cdot 4\end{array}$ & $\begin{array}{r}9.0 \\
+\quad 3.0 \\
-12.0\end{array}$ & $\begin{array}{r}-2.6 \\
+1.0 \\
-3.6\end{array}$ & \\
\hline $\begin{array}{l}\text { B.P. Standing } \\
\text { Sys. P. } \\
\text { Dias. P. } \\
\text { Pulse P. }\end{array}$ & $\begin{array}{l}. \\
\cdots \\
\cdots\end{array}$ & $\begin{array}{l}\cdots \\
\cdots \\
\cdots\end{array}$ & $\begin{array}{r}120 \cdot 3 \\
80 \cdot 3 \\
40 \cdot 0\end{array}$ & $\begin{array}{r}123 \cdot 0 \\
77 \cdot 5 \\
45 \cdot 5 \\
\end{array}$ & $\begin{array}{r}119 \cdot 0 \\
80 \cdot 8 \\
38 \cdot 2\end{array}$ & & $\begin{array}{r}116 \cdot 7 \\
82 \cdot 4 \\
34 \cdot 3 \\
\end{array}$ & & $\begin{array}{r}119 \cdot 0 \\
88 \cdot 3 \\
30 \cdot 7\end{array}$ & \begin{tabular}{|r|}
115.0 \\
79.0 \\
36.0
\end{tabular} & $\begin{array}{r}-1 \cdot 0 \\
+8 \cdot 0 \\
-9.3\end{array}$ & $\begin{array}{r}-8.0 \\
+\quad 1.5 \\
-\quad 9.5\end{array}$ & $\begin{array}{r}-0.0 \\
+\quad 7.5 \\
-7.5\end{array}$ & \\
\hline $\begin{array}{l}\text { Pulse rate pe } \\
\text { Standing }\end{array}$ & er mi & nute & 80 & 85 & & 119 & 80 & 83 & 106 & 108 & +26 & +23 & & \\
\hline $\begin{array}{l}\text { Respiratory } \\
\text { minute }\end{array}$ & rate & per & 20 & 20 & 25 & 25 & 20 & 20 & 25 & 24 & +5 & +4 & & \\
\hline Rectal T. $\left({ }^{\circ} \mathrm{F}\right.$ ) & & . & 98.9 & $98 \cdot 7$ & $98 \cdot 9$ & $99 \cdot 2$ & $98 \cdot 2$ & $9 \cdot 2$ & $98 \cdot 6$ & $98 \cdot 9$ & -0.3 & +0.2 & -0.3 & +0.3 \\
\hline & & & & & & Cor & ite Trials & ( $2 \mathrm{da}$ & & & & & & \\
\hline $\begin{array}{l}\text { B.P. Sitting } \\
\text { Sys. P. } \\
\text { Dias. P. } \\
\text { Pulse P. }\end{array}$ & $\begin{array}{l}\ddot{.} \\
\ddot{*}\end{array}$ & $\begin{array}{l}\cdots \\
\cdots \\
\cdots\end{array}$ & $\begin{array}{r}109 \cdot 0 \\
62 \cdot 3 \\
46 \cdot 7 \\
\end{array}$ & $\begin{array}{r}108 \cdot 0 \\
60 \cdot 3 \\
47 \cdot 7 \\
\end{array}$ & $\begin{array}{r}109 \cdot 0 \\
66 \cdot 2 \\
42 \cdot 8 \\
\end{array}$ & & $\begin{array}{r}100 \cdot 5 \\
64 \cdot 8 \\
35 \cdot 7 \\
\end{array}$ & & $\begin{array}{l}93 \cdot 5 \\
65 \cdot 3 \\
28 \cdot 2\end{array}$ & $\begin{array}{l}94 \cdot 7 \\
72 \cdot 0 \\
22 \cdot 7\end{array}$ & $\begin{array}{r}-15 \cdot 5 \\
+3 \cdot 0 \\
-18 \cdot 5\end{array}$ & $\begin{array}{r}-18 \cdot 3 \\
+11 \cdot 7 \\
-25 \cdot 0\end{array}$ & $\begin{array}{r}-15.5 \\
-0.9 \\
-14.6\end{array}$ & \\
\hline $\begin{array}{l}\text { B.P. Standing } \\
\text { Sys. P. } \\
\text { Dias. P. } \\
\text { Pulse P. }\end{array}$ & $\begin{array}{l}. \\
\cdots\end{array}$ & $\begin{array}{l}\cdots \\
\cdots \\
\cdots\end{array}$ & $\begin{array}{r}125 \cdot 0 \\
83 \cdot 0 \\
42 \cdot 0 \\
\end{array}$ & $\begin{array}{r}118 \cdot 3 \\
77 \cdot 0 \\
41 \cdot 3\end{array}$ & $\begin{array}{r}116 \cdot 8 \\
83 \cdot 0 \\
33 \cdot 8 \\
\end{array}$ & & $\begin{array}{r}107 \cdot 8 \\
82 \cdot 8 \\
25 \cdot 0 \\
\end{array}$ & & $\begin{array}{r}102 \cdot 5 \\
80 \cdot 3 \\
22 \cdot 2 \\
\end{array}$ & \begin{tabular}{|r|}
$103 \cdot 8$ \\
$83 \cdot 2$ \\
$20 \cdot 6$ \\
\end{tabular} & $\begin{array}{r}-22.5 \\
-2.7 \\
-19.8\end{array}$ & $\begin{array}{r}-14.5 \\
+\quad .2 \\
-20.7\end{array}$ & $\begin{array}{r}-14.3 \\
-2.7 \\
-11.6\end{array}$ & \\
\hline $\begin{array}{l}\text { Pulse rate pe } \\
\text { Standing }\end{array}$ & er mi & nute & 89 & 87 & 123 & 117 & 90 & 92 & 118 & 120 & +29 & +33 & & \\
\hline $\begin{array}{l}\text { Respiratory } \\
\text { minute }\end{array}$ & rate & per & 19 & 18 & 25 & 28 & 21 & 20 & 25 & 28 & +6 & +10 & & \\
\hline Rectal T. $\left({ }^{\circ} \mathrm{F}.\right)$ & & .. & $98 \cdot 6$ & $98 \cdot 5$ & $98 \cdot 9$ & $98 \cdot 8$ & $98 \cdot 1$ & $97 \cdot 9$ & $98 \cdot 6$ & 98.4 & -0.0 & -0.1 & -0.3 & -0.4 \\
\hline
\end{tabular}


Estimations of nitrite in the blood were inconclusive. The hæmatological and urine analyses carried out by Dr. Case showed no definite abnormality.

Six of the subjects had a radiographic examination of the chest before commencement of the trials, and again on Wednesday, May 6, 1946, when from one to two days had elapsed since the last exposure to cordite. No abnormality was found.

Acclimatization.- - It had been planned that the cold trials were to be followed by two weeks of intensive acclimatization.- Owing to work on the steam-heating system of the experimental room, the first five of the ten acclimatization days were carried out in another chamber, where it was not found possible to raise the wet bulb above $75^{\circ} \mathrm{F}$. Dry bulbs of $90^{\circ} \mathrm{F}$. on the first two days and $115^{\circ} \mathrm{F}$. on the next three days were attained. As the air movement was high, the conditions were not as severe as those during trials. The next five days of acclimatization were carried out in conditions resembling the experimental series and included two preliminary " dummy " trials, one for each team, inside the experimental room; these were done at a wet bulb at nearly saturated conditions and were more severe than any of the trials.

It is important to note that in these two severe trials the teams were able to complete the experimental routine remarkably well. This indicates that the men had acquired a certain level of acclimatization in spite of the shortcomings of the programme.

TABLE 7A

PHYSIOLOGICAL EFFECTS OF CORDITE AND DUMMY HANDLING AT HIGH TEMPERATURES: TEAM A

\begin{tabular}{|c|c|c|c|c|c|c|c|c|c|c|c|c|c|c|}
\hline \multirow{3}{*}{\multicolumn{4}{|c|}{. }} & \multicolumn{4}{|c|}{ First work } & \multicolumn{4}{|c|}{ Second work } & \multirow{2}{*}{\multicolumn{2}{|c|}{$\begin{array}{l}\text { Col. } 4 \text { vs. } \\
\text { Col. } 1\end{array}$}} & \multirow{3}{*}{$\begin{array}{l}\begin{array}{l}\text { Col. } 4 \\
\text { vs. } \\
\text { Col. } 2\end{array} \\
U\end{array}$} \\
\hline & & & & \multicolumn{2}{|c|}{ Before } & \multicolumn{2}{|c|}{ After } & \multicolumn{2}{|c|}{ Before } & \multicolumn{2}{|c|}{ After } & & & \\
\hline & & & & $\mathbf{U}$ & $\mathbf{P}$ & $\mathbf{U}$ & $\vec{P}$ & $\mathbf{U}$ & $\mathbf{P}$ & $\mathbf{U}$ & $\mathbf{P}$ & $\mathbf{U}$ & $\mathbf{P}$ & \\
\hline & & & & (1) & \multicolumn{7}{|c|}{$\begin{array}{l}\text { DUMMY TRIALS (2 days) } \\
\text { (each figure represents } 4 \text { observations) }\end{array}$} & \multicolumn{2}{|c|}{ (5) } & (6) \\
\hline $\begin{array}{l}\text { B.P. Sitting } \\
\text { Sys. P. } \\
\text { Dias. P. } \\
\text { Pulse P. }\end{array}$ & 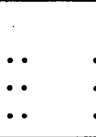 & $\begin{array}{l}\ddot{*} \\
\ddot{*}\end{array}$ & $\begin{array}{l}\ddot{.} \\
\ddot{*}\end{array}$ & $\begin{array}{r}103 \cdot 0 \\
61 \cdot 5 \\
41 \cdot 5\end{array}$ & $\begin{array}{r}106 \cdot 5 \\
61 \cdot 5 \\
45 \cdot 0 \\
\end{array}$ & $\begin{array}{r}101 \cdot 5 \\
69 \cdot 0 \\
32 \cdot 5\end{array}$ & & $\begin{array}{l}98 \cdot 8 \\
61 \cdot 0 \\
37 \cdot 0\end{array}$ & & $\begin{array}{r}100 \cdot 5 \\
67 \cdot 5 \\
33 \cdot 0\end{array}$ & $\begin{array}{l}95 \cdot 0 \\
62 \cdot 5 \\
32 \cdot 5\end{array}$ & $\begin{array}{r}-2.5 \\
+6.0 \\
-8.5\end{array}$ & $\begin{array}{r}-11 \cdot 5 \\
+11 \cdot 0 \\
-12 \cdot 5\end{array}$ & $\begin{array}{r}-1.0 \\
-1.5 \\
+0.5 \\
\end{array}$ \\
\hline $\begin{array}{l}\text { B.P. Standing } \\
\text { Sys. P. } \\
\text { Dias. P. } \\
\text { Pulse P. }\end{array}$ & $\begin{array}{l}\cdots \\
\cdots\end{array}$ & 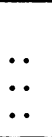 & $\begin{array}{l}\cdots \\
\cdots \\
\cdots\end{array}$ & $\begin{array}{r}111 \cdot 5 \\
75 \cdot 0 \\
36 \cdot 5\end{array}$ & $\begin{array}{r}114 \cdot 5 \\
69 \cdot 0 \\
45 \cdot 5\end{array}$ & $\begin{array}{r}101 \cdot 5 \\
74 \cdot 0 \\
27 \cdot 5\end{array}$ & & $\begin{array}{l}94 \cdot 0 \\
75 \cdot 0 \\
19 \cdot 0\end{array}$ & & $\begin{array}{r}100 \cdot 0 \\
76 \cdot 8 \\
23 \cdot 2\end{array}$ & $\begin{array}{r}102 \cdot 5 \\
80 \cdot 0 \\
22 \cdot 5\end{array}$ & $\begin{array}{r}-11.5 \\
+1.8 \\
-13.3\end{array}$ & $\begin{array}{r}-12 \cdot 0 \\
+11 \cdot 0 \\
-23 \cdot 0\end{array}$ & $\begin{array}{r}-1.5 \\
+\quad 2.8 \\
-4.3\end{array}$ \\
\hline \multicolumn{3}{|c|}{$\begin{array}{l}\text { Pulse Rate Standing ... } \\
\text { Respiratory rate (min.) } \\
\text { Rectal temp. ( }{ }^{\circ} \text { F.) } \\
\text { Net weight loss (g.) . } \\
\text { Sweat in clothes (g.) . }\end{array}$} & $\begin{array}{l}\ddot{\ldots} \\
\ddot{*} \\
\ddot{\ldots} \\
\cdots\end{array}$ & $\begin{array}{l}84 \cdot 0 \\
20 \cdot 0 \\
99 \cdot 3 \\
-\end{array}$ & $\begin{array}{c}97 \cdot 0 \\
22 \cdot 0 \\
99 \cdot 5 \\
- \\
-\end{array}$ & $\begin{array}{r}123.0 \\
30.0 \\
99.9 \\
- \\
-\end{array}$ & $\begin{array}{r}125 \cdot 0 \\
23 \cdot 0 \\
100 \cdot 2 \\
- \\
-\end{array}$ & $\begin{array}{l}77 \cdot 0 \\
22 \cdot 0 \\
99 \cdot 6 \\
- \\
-\end{array}$ & $\begin{array}{l}84 \cdot 0 \\
22 \cdot 0 \\
99 \cdot 9 \\
- \\
-\end{array}$ & $\begin{array}{r}114 \cdot 0 \\
30 \cdot 0 \\
99 \cdot 9 \\
- \\
-\end{array}$ & $\begin{array}{r}160 \cdot 0 \\
29 \cdot 0 \\
100 \cdot 5 \\
- \\
-\end{array}$ & $\begin{array}{c}+30.0 \\
+10.0 \\
+0.6 \\
931 \\
487\end{array}$ & $\begin{array}{r}+63.0 \\
+7.0 \\
+1.0 \\
1354 \\
791\end{array}$ & \\
\hline$\therefore$ & & . & & \multicolumn{8}{|c|}{$\begin{array}{c}\text { CORDITE TRIALs ( } 2 \text { days) } \\
\text { (each figure represents } 4 \text { observations) }\end{array}$} & . & & \\
\hline $\begin{array}{l}\text { B.P. Sitting } \\
\text { Sys. P. } \\
\text { Dias. P. } \\
\text { Pulse P. } \\
\end{array}$ & $\begin{array}{l}\ddot{*} \\
\ddot{*}\end{array}$ & $\begin{array}{l}\ddot{*} \\
\ddot{*}\end{array}$ & $\begin{array}{l}\cdots \\
\cdots \\
\end{array}$ & $\begin{array}{r}102 \cdot 5 \\
53 \cdot 3 \\
49 \cdot 2\end{array}$ & \begin{tabular}{r|}
$105 \cdot 5$ \\
$60 \cdot 5$ \\
$45 \cdot 0$
\end{tabular} & $\begin{array}{l}84 \cdot 0 \\
71 \cdot 0 \\
13 \cdot 0\end{array}$ & & $\begin{array}{l}82 \cdot 0 \\
60 \cdot 5 \\
22 \cdot 5\end{array}$ & & $\begin{array}{l}83 \cdot 5 \\
58 \cdot 5 \\
25 \cdot 0\end{array}$ & $\begin{array}{l}81 \cdot 3 b \\
61 \cdot 3 \\
20 \cdot 0\end{array}$ & $\begin{array}{r}-19 \cdot 0 \\
+5 \cdot 2 \\
-24 \cdot 2 \\
\end{array}$ & $\begin{array}{r}-24.2 \\
+0.8 \\
-25.0 \\
\end{array}$ & $\begin{array}{r}-0.5 \\
-12.5 \\
+12.0 \\
\end{array}$ \\
\hline $\begin{array}{l}\text { B.P. Standing } \\
\text { Sys. P: } \\
\text { Dias. P. } \\
\text { Pulse P. }\end{array}$ & $\begin{array}{l}\ddot{ } \\
\ddot{*}\end{array}$ & $\begin{array}{l}\because \cdot \\
\cdots\end{array}$ & $\begin{array}{l}\ddot{x} \\
\cdots\end{array}$ & $\begin{array}{r}111 \cdot 0 \\
79 \cdot 0 \\
32 \cdot 0\end{array}$ & $\begin{array}{r}113 \cdot 5 \\
75 \cdot 5 \\
38 \cdot 0\end{array}$ & $\begin{array}{l}97 \cdot 0 \\
78 \cdot 5 \\
18 \cdot 5\end{array}$ & & $\begin{array}{l}81 \cdot 3 \mathrm{a} \\
64 \cdot 0 \\
17 \cdot 3\end{array}$ & & $\begin{array}{l}87 \cdot 8 \\
74 \cdot 0 \\
13 \cdot 8\end{array}$ & $\begin{array}{l}81 \cdot 3 b \\
66 \cdot 0 \\
15 \cdot 3\end{array}$ & $\begin{array}{r}-23 \cdot 2 \\
-5 \cdot 0 \\
-18 \cdot 2\end{array}$ & $\begin{array}{r}-32 \cdot 2 \\
-9.5 \\
-22 \cdot 7\end{array}$ & $\begin{array}{r}-9.2 \\
-4.5 \\
-4.7 \\
\end{array}$ \\
\hline $\begin{array}{l}\text { Pulse Rate Star } \\
\text { Respiratory rat } \\
\text { Rectal temp. ( } \\
\text { Net weight loss } \\
\text { Sweat in clothe }\end{array}$ & $\begin{array}{l}\text { anding } \\
\text { ite (min } \\
\text { F.). } \\
\text { is (g.) } \\
\text { es (g.) }\end{array}$ & $\begin{array}{l}\ddot{0} \\
\ddot{0} \\
\ddot{0}\end{array}$ & $\begin{array}{l}\ldots \\
\ldots \\
\cdots \\
\cdots\end{array}$ & $\begin{array}{l}88.0 \\
19.0 \\
99.5 \\
- \\
-\end{array}$ & $\begin{array}{l}87 \cdot 0 \\
20 \cdot 0 \\
99 \cdot 3 \\
- \\
-\end{array}$ & $\begin{array}{r}121 \cdot 0 \\
30.0 \\
99 \cdot 4 \\
- \\
-\end{array}$ & $\begin{array}{r}150 \cdot 0 \\
29 \cdot 0 \\
100 \cdot 0 \\
- \\
-\end{array}$ & $\begin{array}{c}97 \cdot 0 \\
22 \cdot 0 \\
99 \cdot 7 \\
- \\
-\end{array}$ & $\begin{array}{c}21 \cdot 0^{-} \\
99 \cdot 7 \\
- \\
-\end{array}$ & $\begin{array}{r}132 \cdot 0 \\
30 \cdot 0 \\
100 \cdot 1 \\
- \\
-\end{array}$ & $\begin{array}{c}164 \cdot 0 \\
29 \cdot 0 \\
100 \cdot 3 \\
- \\
-\end{array}$ & $\begin{array}{c}+44.0 \\
+11.0 \\
+0.6 \\
733 \\
417\end{array}$ & $\begin{array}{c}+77.0 \\
+9.0 \\
+1.0 \\
1326 \\
579\end{array}$ & \\
\hline
\end{tabular}




\section{Discussion}

The experiments detailed above make clear the detrimental effects of handling cordite as compared with handling dummies, both in cool and in hot humid environments. As already mentioned the dummy bags were easily distinguished from the cordite bags ; owing to the particular circumstances of the investigation the difficulties in making the bags really comparable could not be overcome. Thus, after stoving - the necessary preliminary to these experiments-the fabric surrounding the cordite charges became discoloured, corroded, and rather.friable. To simulate this covering on the dummies would have required the provision of an identical covering, using perhaps bags in which cordite had previously been stored after all traces of nitroglycerine and their products had been removed. Again, after stoving, the characteristic smell of the cordite would need to be simulated, also a very difficult task.

These differences between the dummy and.cordite days must of course be borne in mind in assessing the significance of the subjective effects associated specifically with cordite handling. Apart from the

TABLE 7B

PHYSIOLOGICAL EFFECTS OF CORDITE AND DUMMY HANDLING IN HIGH TEMPERATURES : TEAM B

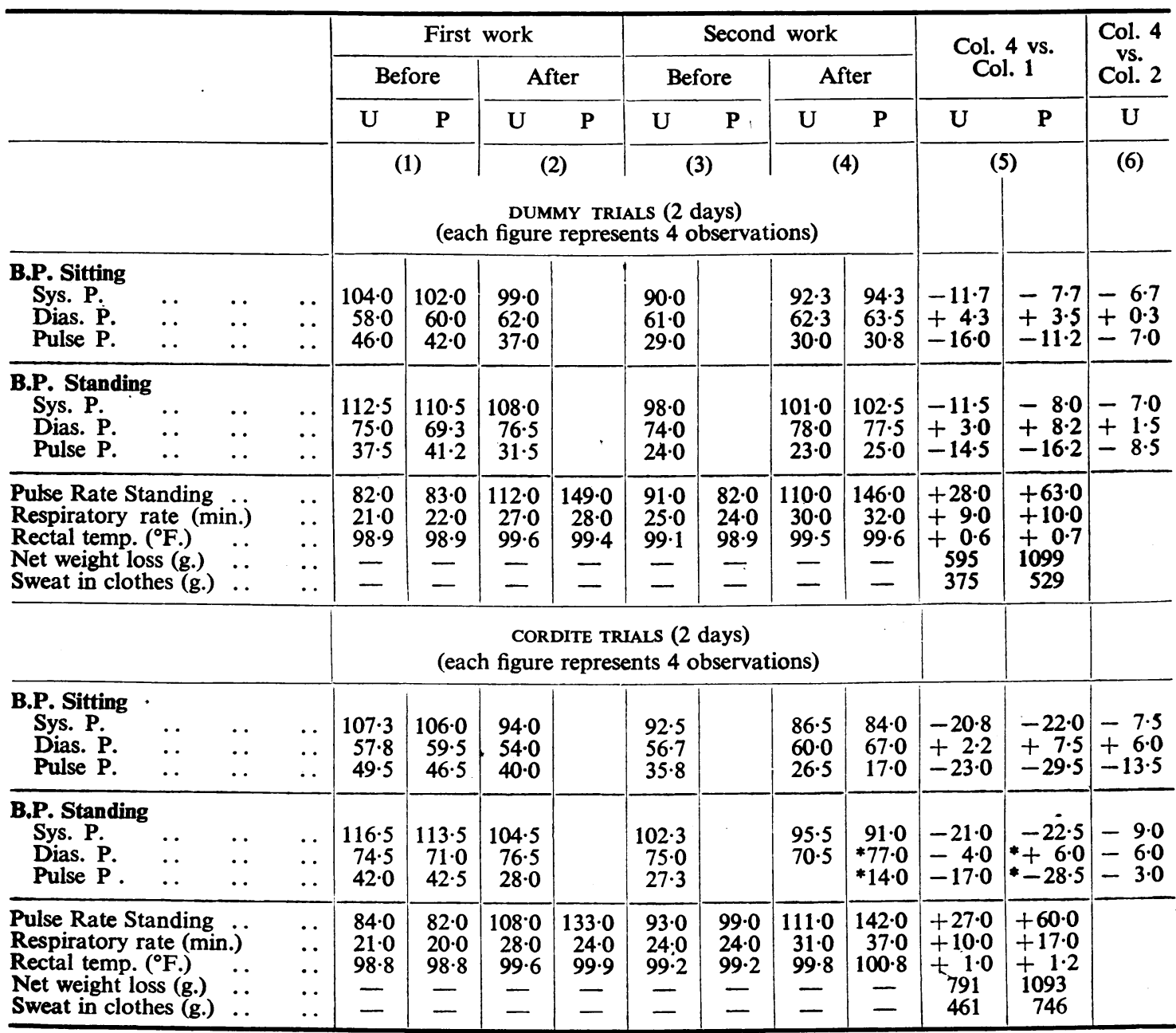


fact that these particular effects were noted by the observers as well as the subjects and were of a characteristic kind, the general conclusions of this study are based also on the changes in work capacity and blood pressure, and these findings fully support the subjective data.

Effects of Cordite Products.-Nitroglycerine and nitrocellulose are the main constituents of cordite, with a smaller amount of carbamite. Nitrocellulose is not volatile ; carbamite has a very low vapour pressure; nitroglycerine has also a low vapour pressure, but has an exceptionally powerful pharmacological effect.

The gaseous products found after "ageing" of cordite are nitrous fumes, carbon dioxide, carbon monoxide, and an unidentified acrid component. The presence of nitroglycerine vapour was inferred from vapour-pressure considerations.

The circulatory effects (headache and fall in blood pressure) experienced by our subjects during cordite trials resembled closely those known to occur after the ingestion or inhalation of nitroglycerine, both in treatment and during the manufacture of

\section{TABLE 8}

CHANGE IN SYSTOLIC BLOOD PRESSURE DURING CORDITE TRIALS COMPARED WITH THAT DURING DUMMY TRIALS*

\begin{tabular}{|c|c|c|c|c|}
\hline \multirow[b]{3}{*}{$\begin{array}{l}\text { No. of observations } \\
\text { distributed in pairs }\end{array}$} & \multicolumn{2}{|c|}{$\begin{array}{l}\text { Temperate } \\
\text { conditions }\end{array}$} & \multicolumn{2}{|c|}{$\begin{array}{c}\text { Hot - } \\
\text { conditions }\end{array}$} \\
\hline & $\begin{array}{l}\text { Sitt- } \\
\text { ing }\end{array}$ & $\begin{array}{l}\text { Stand- } \\
\text { ing }\end{array}$ & $\begin{array}{l}\text { Sitt- } \\
\text { ing }\end{array}$ & $\mid \begin{array}{l}\text { Stand- } \\
\text { ing }\end{array}$ \\
\hline & 20 & 20 & 30 & 30 \\
\hline $\begin{array}{l}\text { Degrees of freedom } \\
\text { Cordite vs. dummy } \\
\text { Experimental days } \\
\text { Error }=\mathrm{N}\end{array}$ & $\begin{array}{l}1 \\
9 \\
9\end{array}$ & $\begin{array}{l}1 \\
9 \\
9\end{array}$ & $\begin{array}{r}1 \\
14 \\
14\end{array}$ & $\begin{array}{r}1 \\
14 \\
14\end{array}$ \\
\hline Total & 19 & 19 & 29 & 29 \\
\hline $\begin{array}{l}\text { Mean difference be- } \\
\text { tween cordite and } \\
\text { dummy trials in } \\
\text { change of Sys. B.P. } \\
\text { (m.m.) (d) }\end{array}$ & $11 \cdot 1$ & $19 \cdot 3$ & $13 \cdot 4$ & 15.07 \\
\hline 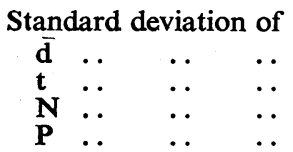 & $\begin{array}{c}4 \cdot 38 \\
2 \cdot 53 \\
9 \\
0 \cdot 05-0 \cdot 02\end{array}$ & $\begin{array}{c}7 \cdot 12 \\
2 \cdot 71 \\
9 \\
0 \cdot 05-0 \cdot 02\end{array}$ & $\begin{array}{c}3 \cdot 34 \\
4 \cdot 02 \\
14 \\
0 \cdot 001\end{array}$ & $\begin{array}{c}2 \cdot 41 \\
6 \cdot 24 \\
14 \\
0 \cdot 001\end{array}$ \\
\hline
\end{tabular}

* The mean difference between the S.B.P. changes in the two series is estimated taking results of each man separately for "protected" and "unprotected" observations. This eliminates variance due to "experimental days". The variance due to the two sets of clothing and the interaction between clothing and experimental treatment (i.e. cordite or dummy) remain within the error variance. explosives (Rabinowitch, 1944). Apart from nitroglycerine, other possible causes of the headache are the high carbon dioxide concentration and carbon monoxide poisoning.

Carbon dioxide was not of itself causative since, although it was present in comparable amounts in all trials, no headaches occurred on dummy days, either during exposure or on entering the fresh air. The latter, or " paradox" effect, was not produced, presumably because carbon dioxide at 3 to 4 per cent. was breathed for a relatively short time. Furthermore, headaches often came on in the first hour of the cordite trial before carbon dioxide had reached 1 per cent. By increasing pulmonary ventilation, carbon dioxide would, presumably, increase the absorption of nitroglycerine vapour (and other gases present).

Carbon monoxide was present in such small concentrations that it is unlikely to have had any effect, and was present on one "dummy" trial (May 9, 1946) in amounts comparable to one of the "headache-producing" cordite trials (May 31, 1946). The maximum figure for any trial was 0.002 per cent. (average for trial, 0.0017 per cent.) on May 7, 1946. This is quite unlikely to have caused symptoms. The dangerous limit for continuous work is given as 0.01 per cent. by the Air Ministry. Killick (1936) found negligible symptoms from continuous exposure of over four hours to 0.04 per cent. carbon monoxide while resting. It will be recalled however, that nothing is known about the maximum amounts of carbon monoxide which may occur inside cylinders of " aged " cordite, and the possibility therefore that toxic concentrations of carbon monoxide (and also nitrogen dioxide) may be produced from a batch of stoved cordite cannot be ruled out.

As the present experiments show, heat alone can cause a reduction in the blood pressure of working subjects. Moreover, the collapse noted in association with low systolic blood pressure is similar to heat syncope (Weiner, 1938). Comparison of hot dummy and cordite trials, however, shows that cordite was specifically responsible for the adverse circulatory effects noted in the present trials.

Nitroglycerine, therefore, remains as the likely factor producing the ill-effects observed in the present experiments. The presence of nitroglycerine vapour could not be proved chemically, but, as already stated, it was calculated to be present in minute quantities. The vapour of nitroglycerine is known to be a powerful poison even when much diluted with air (Laws, 1898), and it must be assumed that these minute quantities were absorbed through the lungs in amounts sufficient to produce adverse effects in our non-immune men. 
To determine the role played by nitroglycerine in producing these circulatory effects, further investigation is required, using a pure source of nitroglycerine such as dynamite (nitroglycerine in Kieselguhr). A study using amounts comparable to the theoretical quantities which our subjects may have absorbed is clearly indicated.

The irritant effects of cordite on the nasal mucosa are probably not due to nitrous fumes. The reasons for ruling out nitrogen dioxide are first its distinctive and recognizable odour, and, secondly, the extremely low concentration in which it was present in the air of the trial room. The maximum found $(0.00067$ per cent.) is below the maximum concentration of 0.001 per cent., allowable for an exposure of several hours' duration. Lehmann (1939) states that $\mathbf{0 . 0 0 6}$ per cent. is required to produce moderate irritation of the larynx, and that 0.004 per cent. could be tolerated for several hours by many persons.

The clinical features of nitrous fume poisoning include changes in radiographic appearances of the lungs (Camiel and Berkhan, 1944). Methæmoglobin formation, and other alterations in the blood picture have been reported-relative lymphocytosis, eosinophilia, delayed sedimentation rate (Pfenninger, 1944), and an increase in blood platelet count.

None of the examinations made on these points provides evidence of toxic nitrogen dioxide effects. Radiographs of chests showed no abnormality; methæmoglobin could not be detected in any but insignificant amounts (one estimation only); Dr. Case's blood cytological studies also failed to show abnormalities. It is unlikely that the present methods for estimating nitrite in body fluids would reveal the small amounts absorbed either as nitrous fumes or from inhaled nitroglycerine.

Mode of Absorption.-Apart from ingestion by mouth, it is generally recognized that nitroglycerine may be absorbed both by inhalation and through the skin (Rabinowitch, 1944). Earlier investigators believed that during the cordite handling inhalation of the fumes alone could induce the symptoms. The use of protective clothing in the present trials confirms this belief, since all the adverse effects could be produced in subjects wearing the protective garments. In subjects not so protected there is no doubt that skin absorption of nitroglycerine was possible. The content of nitroglycerine in the anti-flash gloves after cordite handling was appreciable (see under "Results").

Susceptibility and Immunity.-There is a wide variation in susceptibility to nitroglycerine (Rabinowitch, 1944). One of our eight subjects appeared to be unaffected in any way throughout the trials; on the other hand the authors suffered headaches every time they were exposed.

All but 2 to 3 per cent. of nitroglycerine workers acquire an immunity to nitroglycerine after three or four days (Ebright, 1914) which may, however, be lost over the week-end (presumably two days). The workers are said to rub nitroglycerine into their hatbands to avoid "Monday headache." This immunity is said to be lessened by hot weather and by indulgence in alcohol.

Our programme was planned to allow three days between cordite trials for the subjects, so as to reduce or eliminate any immunity from the previous exposure. It was, however, difficult to avoid slight exposure on intervening days due to diffusion from the closed cordite cases during the laborious procedure of changing the cases at the end of a trial in preparation for the next. This fact would help to explain the lessened evidence of ill-effects on our second cordite exposures. It seems likely also that a pause of three days is not entirely sufficient to abolish acquired immunity.

\section{Summary}

The effects were determined of " aged" cordite on the efficiency of young adults handling it in the form of $96 \mathrm{lb}$. quarter charges, at a moderate rate of work in a small airtight compartment.

At ordinary room temperature cordite products produced no definite impairment of the ability to perform this type of work.

At wet-bulb temperatures of the order of $86^{\circ} \mathrm{F}$. the efficiency of the men was definitely reduced.

The main symptoms were those of nitroglycerine poisoning. Nitrous fumes and carbon monoxide were liberated when the cordite cases were opened, but in quantities unlikely to cause symptoms.

Comparative trials conducted on a group of men protected against the absorption of cordite through the skin by impermeable rubber gloves and aprons, suggested that the main channel of absorption of cordite products was by inhalation.

Thanks are due to Mr. T. G. Bonner, Dr. R. A. M. Case, and Dr. E. M. Jope, for chemical and biological estimations ; to Drs. G. Weddell, B. McArdle, and J. A. B. Gray for advice ; and to Corporal C. Colquhoun and Petty Officer R. Baldock for technical assistance.

\section{REFERENCES}

Camiel, M. R., and Berkhan, H. S. (1944). Radiology, 42, 175. Ebright, G. E. (1914). J. Amer. med. Ass., 62, 201. Killick, E. M. (1936). J. Physiol., 87, 41.

Laws, G. C. (1898). J. Amer. med. Ass., 31, 793.

Lehmann, K. (1939). Quoted in M.R.C. Special Report. "Chronic Pulmonary Disease in South Wales Coal Miners." Part II, Environmental Studies (1943).

Pfenninger, E. (1944). Bull. Hyg. Lond., 19, 363.

Rabinowitch, I. M. (1944). Canad. med. Ass. J., 50, 199.

Weiner, J. S. (1938). J. industr. Hyg., $20,389$. 

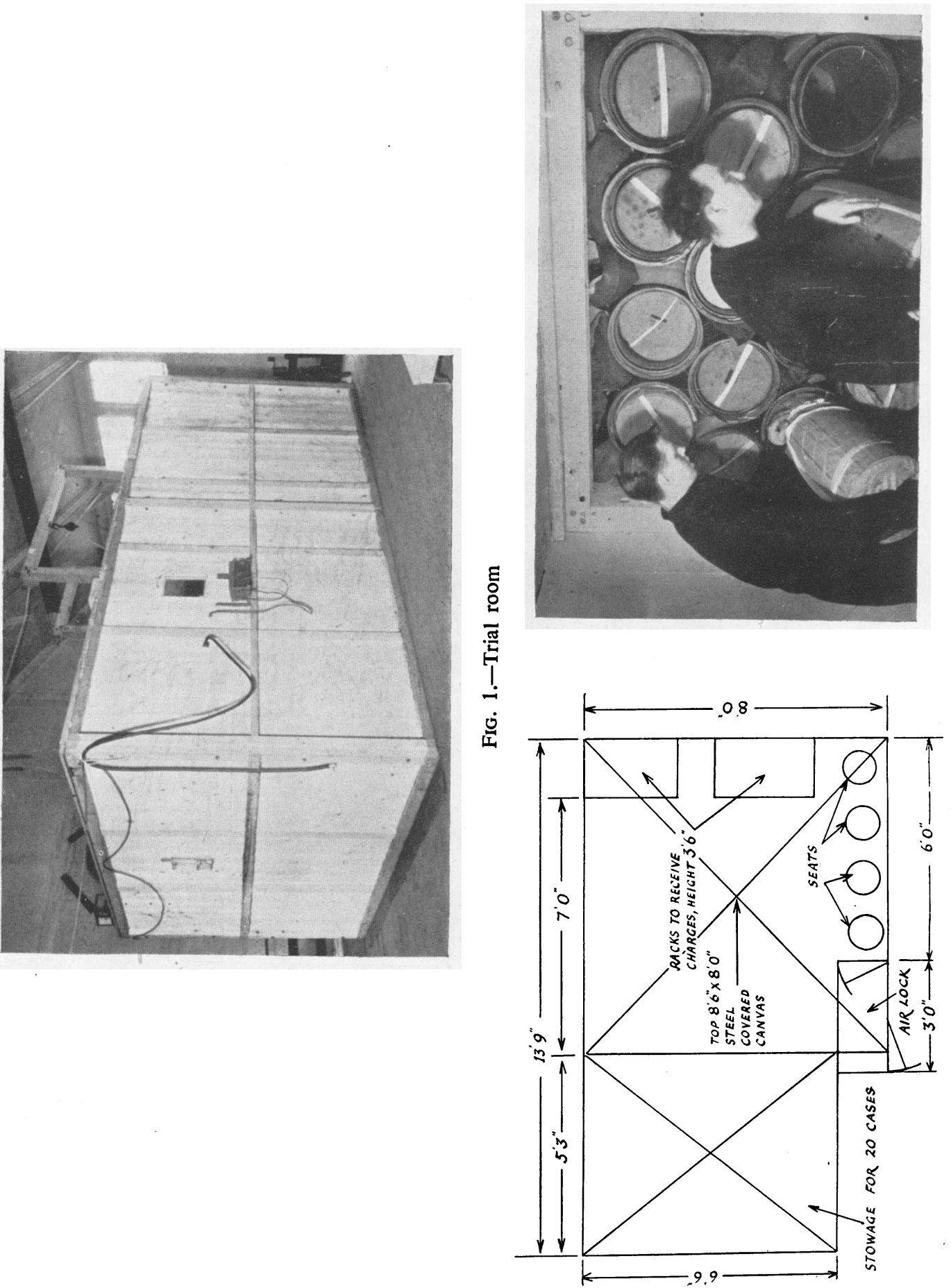